\title{
A review of the Quaternary Scelidotheriinae (Mammalia, Xenarthra, Tardigrada) from the Tarija-Padcaya basin, Bolivia
}

\author{
ÁNGEL R. MIÑO-BOILINI ${ }^{1,3}$, ALFREDO A. CARLINI ${ }^{2,3}$, ALFREDO E. ZURITA ${ }^{1,3}$, \\ ESTEBAN SOIBELZON ${ }^{2,3}$ and SANTIAGO M. RODRÍGUEZ-BUALÓ ${ }^{1,3}$ \\ ${ }^{1}$ Centro de Ecología Aplicada del Litoral/CECOAL-CONICET y Universidad Nacional \\ del Nordeste, Ruta 5, Km 2,5 (CP 3400, CC 128), Corrientes, Argentina \\ ${ }^{2}$ División Paleontología Vertebrados, Facultad de Ciencias Naturales y Museo de La \\ Plata, Paseo del Bosque, s/n, (1900) La Plata, Buenos Aires, Argentina \\ ${ }^{3}$ Consejo Nacional de Investigaciones Científicas y Técnicas, Godoy Cruz 2290 (C1425FQB), Buenos Aires, Argentina \\ Manuscript received on May 23, 2017; accepted for publication on November 15, 2017
}

\begin{abstract}
How to cite: MIÑO-BOILINI AR, CARLINI AA, ZURITA AE, SOIBELZON E AND RODRÍGUEZ-BUALÓ SM. 2019. A review of the Quaternary Scelidotheriinae (Mammalia, Xenarthra, Tardigrada) from the Tarija-Padcaya basin, Bolivia. An Acad Bras Cienc 91: e20170390. DOI 10.1590/0001-3765201720170390.
\end{abstract}

\begin{abstract}
The Mylodontidae Scelidotheriinae (Mammalia, Xenarthra, Tardigrada) are a diversified clade of South American fossil ground sloths, with a wide geographic distribution, especially in high and middle latitudes. According to the last revision, the Quaternary diversity includes the genera Scelidotherium, Catonyx, and Valgipes. The clade Scelidotheriinae is well represented in the Pleistocene of the TarijaPadcaya basin, and the first mention of these ground sloths correspond to the middle of the XIX Century. Since then, several species (i.e., Scelidotherium tarijensis, Scelidodon tarijensis, Scelidotherium capellini) have been reported as inhabiting the Tarija-Padcaya basin during the Pleistocene. Despite the abundance of fossil records of Scelidotheriinae in this area, no modern taxonomic revisions are available. In consequence, in this contribution a revision of the remains assigned to Scelidotheriinae from the Tarija-Padcaya basin is accomplished, and some biostratigraphic and geographic implications are discussed. Our results show that one single species (Catonyx tarijensis) can be recognized in the studied area, whereas a supposed smaller one (Scelidotherium patrium) actually corresponds to juvenile specimens of C. tarijensis.
\end{abstract}

Key words: Catonyx, Diversity, Pilosa, Pleistocene, South America.

\section{INTRODUCTION}

The Tarija-Padcaya basin is located in southern Bolivia, $140 \mathrm{~km}$ north of Argentina (see map in Tonni et al. 2009). This locality is known for its high diversity of Pleistocene mammals since the

Correspondence to: Ángel R. Miño-Boilini E-mail: angelmioboilini@yahoo.com.ar ORCid: http://orcid.org/0000-0003-0331-8068

* Contribution to the centenary of the Brazilian Academy of Sciences.
XIX Century, being one of the most important in South America (see, among others, Gervais 1855, Ameghino 1902, Boule and Thévenin 1920, Tonni et al. 2009).

According to Hoffstetter (1963) and Tonni et al. (2009) the main groups of Pleistocene mammals of Tarija are represented by Didelphimorphia, Xenarthra, Carnivora, Rodentia, Liptopterna, Notoungulata, Perissodactyla, and Artiodactyla. In this context, xenarthrans are one of the most 
conspicuous groups in the Quaternary palaeofauna from the Tarija-Padcaya basin, both in diversity and abundance (Boule and Thévenin 1920, Hoffstetter 1963, Takai et al. 1982, 1984). In recent times, the taxonomy of some groups was updated, especially the families Megatheriidae (De Iuliis et al. 2009), Glyptodontidae (Zurita et al. 2009), Pampatheriidae (Rodríguez-Bualó et al. 2014a), and Dasypodidae (Rodríguez-Bualó et al. 2014b, 2017).

In turn, the ground sloth clade Mylodontidae Scelidotheriinae (Xenarthra, Tardigrada) is represented by several records in the Pleistocene palaeofauna of Tarija-Padcaya (see Boule and Thévenin 1920, Hoffstetter 1963, Takai et al. 1982, 1984), which were studied in the Ph.D. theses of McDonald (1987) and Miño-Boilini (2012); however, their results are still in part unpublished.

From a taxonomic perspective, the clade Scelidotheriinae (typified by Scelidotherium Owen 1839) is one of the most diversified among Mylodontidae. In this context, the Quaternary taxa are represented by three genera: Scelidotherium Owen 1839, Valgipes Gervais 1874, and Catonyx Ameghino 1891 (see Corona et al. 2013, MiñoBoilini 2016). Scelidotherines are recorded from the middle Miocene to the early Holocene in Argentina, Bolivia, Brazil, Chile, Colombia, Ecuador, Peru, Paraguay, and Uruguay (Miño-Boilini and Carlini 2009). Despite their wide geographic distribution in South America, they are the only mylodontoids which did not migrate to Central and North America during the Great American Biotic Interchange (McDonald and Perea 2002).

From an anatomical viewpoint, scelidotherines are characterized by having a tubular and elongate skull (McDonald and Perea 2002), parallel dental series, laterally compressed molariforms (Pascual et al. 1966), and quadrangular and anteroposteriorly compressed femur, with concave facet of the astragalus for the cuboid (Pascual et al. 1966, McDonald and Perea 2002).
This paper aims to: a) carry out a taxonomic revision of the Scelidotheriinae specimens from the Tarija-Padcaya basin (Bolivia), including the descriptions of new specimens; b) discuss the chronostratigraphic and biogeographic implications.

\section{PREVIOUS STUDIES AND REPORTS OF SCELIDOTHERIINAE IN BOLIVIA}

The first mention of scelidotheres from Bolivia are those of Gervais (1855), Gervais and Ameghino (1880), Philippi (1893), and Sefve (1915a, b). More precisely the first Bolivian remains were exhumed by Weddell from the Tarija Valley (Weddell 1851), and were later mentioned and figured by Paul Gervais (1855: Plate 11 Figure 2, Plate 13 Figures 4-5). Sixty years later, Sefve (1915a) described and illustrated some specimens referred to Scelidotherium capellini from the same area.

In an outstanding contribution, Boule and Thévenin (1920) mentioned the presence of two scelidotheres in Tarija: Scelidotherium tarijense Gervais and Ameghino, 1880 (articulated skull and mandible, Plate XXIII, Figure 2, type of Catonyx tarijensis, and one calcaneus, Plate XXIV Figure 6), and Scelidotherium patrium Ameghino, 1888 (represented by a small partial dentary, which unfortunately was not figured).

Later, in an important field expedition to the Tarija-Padcaya basin carried out between 19241927, Riggs collected a large amount of remains that were assigned to Scelidotherium and are housed in the FMNH collections (Chicago, USA) (see Marshall 1978).

Hoffstetter (1963) reported the presence of Scelidodon tarijensis, and Takai et al. $(1982,1984)$ mentioned specimens referred to Scelidotherium capellini collected at the upper, middle, and lower members of the "Tarija Formation" (=Tolomosa Formation) (see Takai et al. 1982, Table I). 
More recently, Werdelin (1991) mentioned specimens referred to Scelidodon tarijensis, which were collected by a Swedish expedition under the direction of Earland Nordenskiöld in 1901-1902 (Nordenskiöld 1902).

In summary and from a historical perspective, the scelidotheres reported as part of the Pleistocene paleofauna of the Tarija-Padcaya basin are: Scelidotherium tarijense, Scelidodon tarijensis, Scelidotherium capellini, and Scelidotherium patrium (see Gervais and Ameghino 1880, Sefve 1915a, Boule and Thévenin 1920, Hoffstetter 1963, Takai et al. 1982, 1984, Werdelin 1991).

\section{GEOLOGY AND AGE OF TARIJA-PADCAYA}

The Tarija-Padcaya basin is located between $21^{\circ}$ $19^{\prime}$ and $21^{\circ} 50^{\prime} \mathrm{S}$ and $64^{\circ} 35^{\prime}$ and $64^{\circ} 50^{\prime} 0 \mathrm{~W}$, ranging from 1600 to $2200 \mathrm{~m}$ above sea level (see Tonni et al. 2009, Coltorti et al. 2010). It is part of a Quaternary basin filled with fluvial-lacustrine sediments that discordantly overlie the Paleozoic basement (Suárez-Montero 1996), showing a characteristic landscape of badlands, with irregular relief produced by differential sediment erosion (Oppenheim 1943, Suárez-Montero 1996). Recently Coltorti et al. (2010) included the entire Pleistocene sequence of the Tarija valley within the Tolomosa Formation, subdivided into three main sub-synthem named Ancon Grande, Puente Phayo, and San Jacinto.

The age of the Tarija palaeofauna is still problematic. Recent studies, including magnetostratigraphy dating, suggested very different interpretations for those levels bearing fossil mammals. When compared to the biochronologic framework of the Argentinean Pampean Region (see Cione et al. 2015), MacFadden et al. (2013) proposed they are exclusively Ensenadan in age (early to middle Pleistocene), but according to Coltorti et al. (2010) they are Lujanian (late Pleistocene), or even Ensenadan-Lujanian according to Tonni et al. (2009).

\section{MATERIALS AND METHODS}

The chronologic scale is based on Cione et al. (2015), whereas the stratigraphy follows Coltorti et al. (2007, 2010).

Recently, Miño-Boilini (2016) carried out a detailed anatomical description of the skull, mandible and other postcranial elements (e.g.: scapula, humerus, radius, ulna, femur, tibia, and astragalus) of C. tarijensis, including comparisons with other Quaternary Scelidotheriinae. Consequently, in this contribution only the diagnostic characters of the materials are considered in order to support the specific assignation.

Institutional abbreviations: FMNH P: Field Museum of Natural History, Chicago, USA; MACN: Sección Paleontología Vertebrados, Museo Argentino de Ciencias Naturales "Bernardino Rivadavia", Buenos Aires, Argentina; MNPA: Museo Nacional Paleontológico-Arqueológico, Tarija (ex MUT: Museo Universitario de Tarija), Bolivia; MNHN TAR: Muséum National d'Histoire Naturelle, Tarija collection, Paris, France; NRM-M: Swedish Museum of Natural History, Stockholm, Sweden, Nordenskiöld collection.

Anatomical abbreviations: Mf/mf: upper/lower molariform, respectively.

Other abbreviations: $\mathrm{n} / \mathrm{n}$ : without official catalogue number.

\section{SYSTEMATIC PALEONTOLOGY}

Xenarthra Cope, 1889

Tardigrada Lathan and Davis in Forster, 1795

Scelidotheriinae Ameghino, 1904

Catonyx Ameghino, 1891

Included species: Catonyx cuvieri (Lund, 1839), Catonyx tarijensis (Gervais and Ameghino, 1880), and Catonyx chiliensis (Lydekker, 1886).

Catonyx tarijensis (Gervais and Ameghino, 1880) 

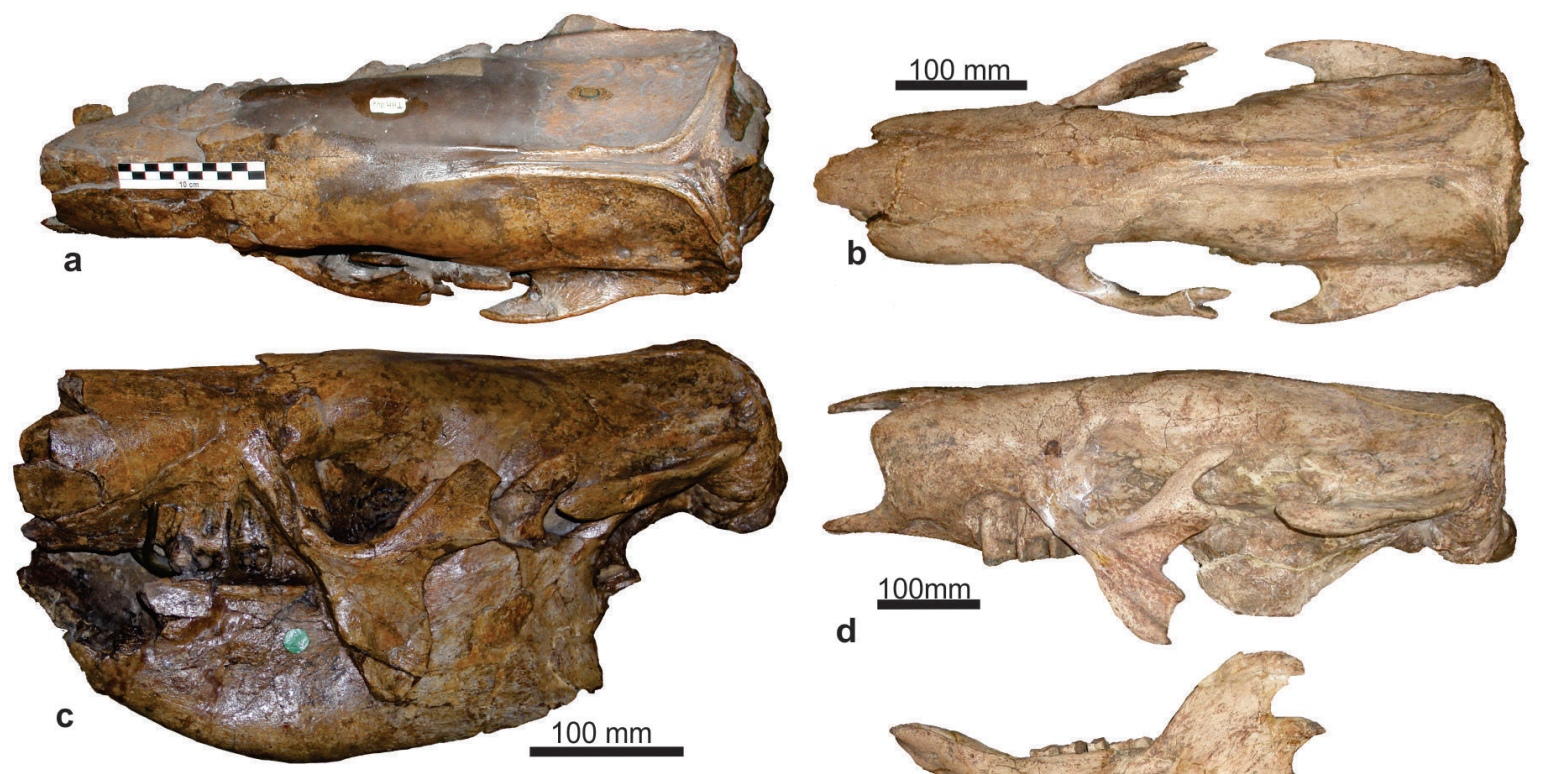

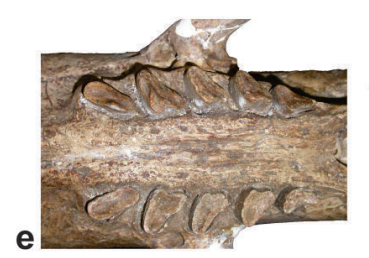

$20 \mathrm{~mm}$
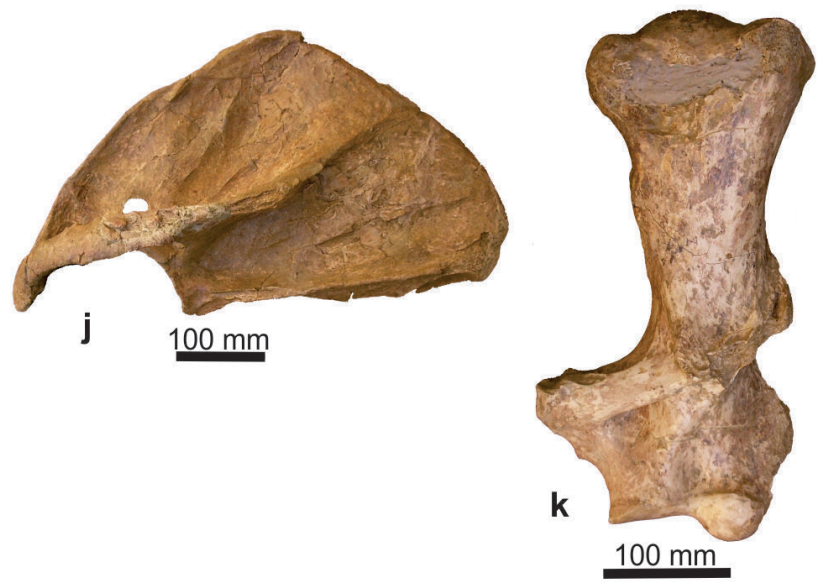
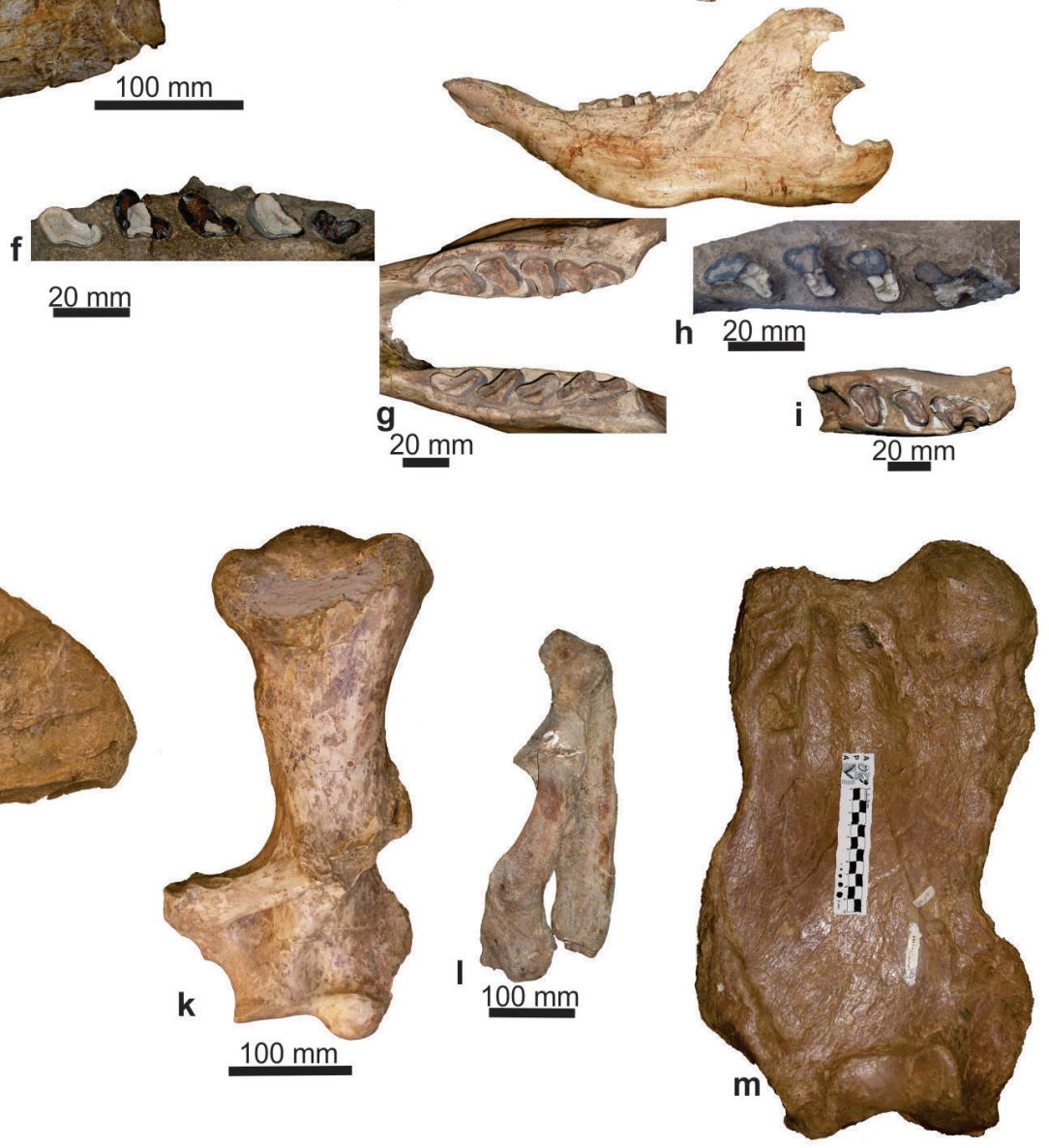

Figure 1 - Catonyx tarijensis (Gervais and Ameghino 1880), a) skull in dorsal view (MNHN TAR 1260, holotype of Scelidotherium tarijense); b) skull in dorsal view (FMNH P 14243); c) skull and mandible in lateral view (MNHN TAR 1260, holotype of Scelidotherium tarijense); d) skull and mandible in lateral view (FMNH P 14243); e) upper dental series in occlusal view (FMNH P 14243); f) left upper dental series in occlusal view (MNPA-V n/n, ex MUT 452, juvenile); g) lower dental series in occlusal view (FMNH P 14243); h) right lower dental series in occlusal view (MNPA-V n/n, ex MUT 451, juvenile); i) right lower dental series in occlusal view (MNPA-V n/n, ex MUT 438, juvenile); j) left scapula in lateral view (MNPA-V 005752); k) left ulna and left radius in lateral view (FMNH P 14238); l) left humerus in anterior view (MNPA-V 005752); m) right femur anterior view (MNPA-V 005764). 


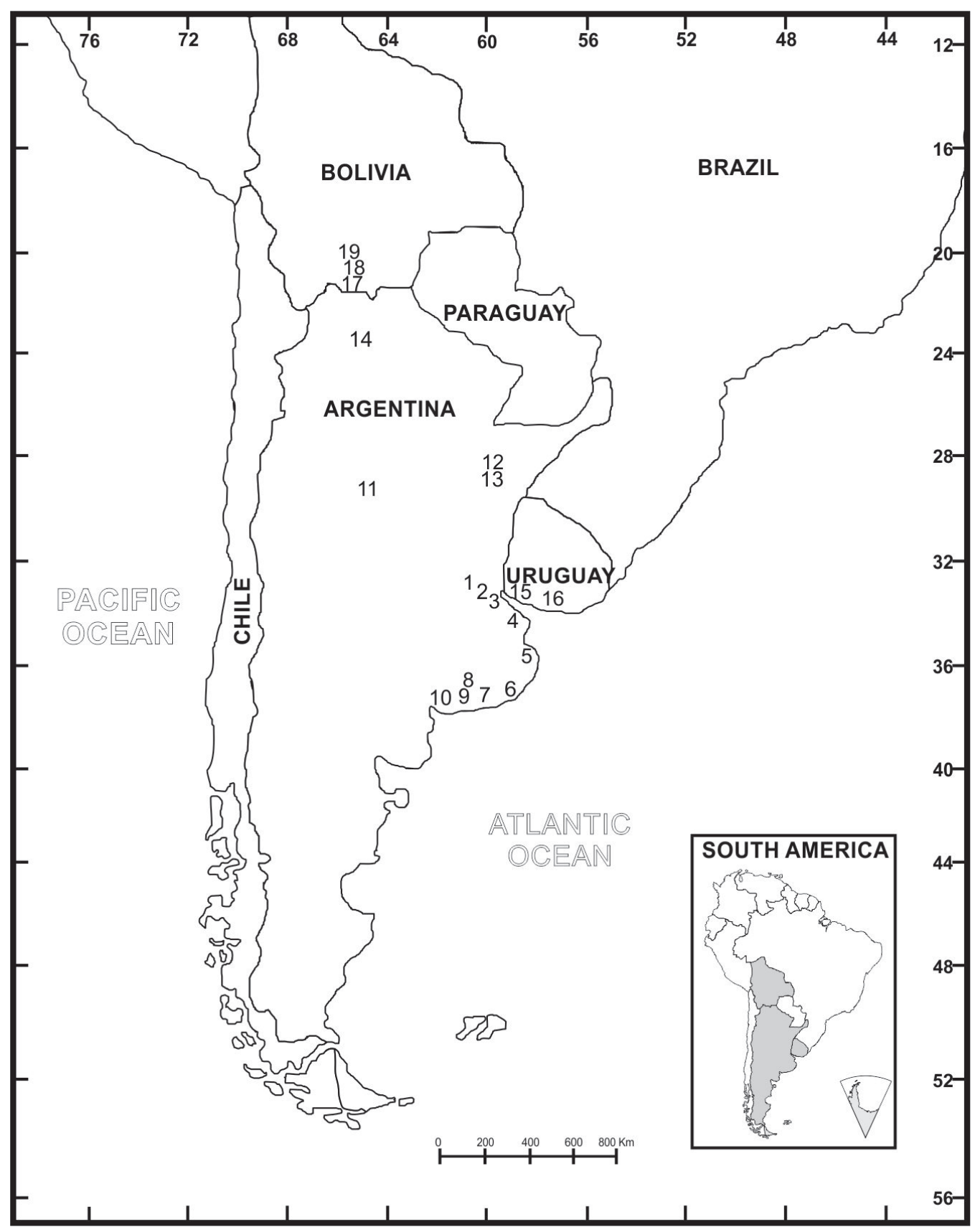

Figure 2 - Geographic distribution of Catonyx tarijensis (Gervais and Ameghino, 1880) in South America. 1) Arroyo Maciel, Buenos Aires Province, Argentina; 2) “Toscas” del Río de La Plata, Buenos Aires Province, Argentina; 3) Ciudad Autónoma de Buenos Aires, Buenos Aires Province, Argentina; 4) La Plata, Buenos Aires Province, Argentina; 5) Mar del Plata, Buenos Aires Province, Argentina; 6) Miramar, Buenos Aires Province, Argentina; 7) Necochea, Buenos Aires Province, Argentina; 8) Olavarría, Buenos Aires Province, Argentina; 9) río Quequén, Buenos Aires Province, Argentina; 10) Playa del Barco, Buenos Aires Province, Argentina; 11) Río Tercero, Córdoba Province; 12) Bella Vista, Corrientes Province; 13) Lavalle, Corrientes Province; 14) Guachipas, Salta Province; 15) Puerto Arazatí, Department of San José, Uruguay; 16) San Ramón, Department of Canelones, Uruguay; 17) Padcaya, Tarija, Bolivia; 18) Tarija, Bolivia; 19) Turamayo, Tarija, Bolivia. [1 - 14, see Miño-Boilini (2016); 15 and 16, see McDonald and Perea (2002), Corona et al. (2013)]. 
Figure 1 and 2

Holotype: MNHN TAR 1260, articulated skull and mandible.

Type locality and age: Department of Tarija, Bolivia, Tolomosa Formation, Pleistocene.

Description of the holotype: MNHN TAR 1260 (Figure 1a and c) is composed of an articulated partial skull and mandible, which precludes detailed descriptions. The narrow and elongate skull belongs to a large specimen, with an approximate length of $580 \mathrm{~mm}$ from the posterior end of the occipital condyles to the anterior end of the maxillaries.

In dorsal view, the parasagittal crests form an evident sagittal crest; the supraoccipital and occipital crests, as well as the external protuberances of the occipital, which are very developed, can also be observed. There is also a slight postorbital narrowing. The fronto-parietal suture is located behind the anterior part of the zygomatic process of the squamosal. In lateral view, the zygomatic process of the squamosal is very robust, whereas the lacrimal preserves a vestige of the suture with the frontal and the parietal. In anterior view, the contour formed by the nasals, maxillaries, and the palate is sub-circular. Finally, in posterior view, the foramen magnum is sub-circular. The left hemimandible is robust; in lateral view, the horizontal ramus is high and ventrally convex. The mandibular condyle is slightly above the occlusal surface of the dental series.

REFERRED MATERIAL, GEOGRAPHIC AND STRATIGRAPHIC PROVENANCE

Department of Tarija, Bolivia, Tolomosa Formation, Pleistocene: FMNH P 14238: skull, mandible, left scapula, right and left humeri, left ulna, left radius and left femur; MNPA-V 005752: left scapula, left humerus, left ulna, and left radius; MNPA-V 005769: skull and mandible dorso-ventrally compressed by lithostatic pressure; MNPA-V 005750 (ex MUT-V 32): skull and mandible; MNPA-V n/n (ex MUT 166): articulated skull and mandible; MNPA-V 005766 (ex MUT 298): skull and partial left mandible; MNPA-V n/n (ex MUT 299): partial skull; MNPA-V n/n (ex MUT 368): partial mandible; MNPA-V n/n (ex MUT 446): partial mandible; MNPA-V n/n (ex MUT 447): partial left mandible; MNPA-V n/n (ex MUT 448): partial right mandible; MNPA-V n/n (ex MUT 449): partial right mandible; MNPA-V n/n (ex MUT 007): partial mandible; MNPA-V s/n (ex MUT 451): partial mandible belonging to a juvenile specimen; MNPA-V s/n (ex MUT 452): partial left maxillary belonging to a juvenile specimen; MNPA-V s/n (ex MUT 443 and 438): partial mandible of a juvenile specimen; MNPA-V n/n (ex MUT 338): partial left mandible; MNPA-V n/n (ex MUT 450): partial left mandible; FMNH P 13733: partial skull; NRM-M 4678: anterior part of right mandible; NRM-M 4731: partial left mandible; NRM-M 4444: skull and mandible; MACN 1138: posterior part of skull; MACN 1137 : partial right mandible; and MACN 1139: left femur. Padcaya, Department of Tarija, Pleistocene: FMNH P 14243: skull and mandible.

Turamoyo, Department of Tarija, Pleistocene: FMNH P 13646: partial mandible; FMNH P 13741: isolated teeth and vertebrae.

DESCRIPTION OF THE REFERRED MATERIAL

\section{Skull}

In anterior view, the nasal opening of $C$. tarijensis is sub-circular in cross section [MNHN TAR 1260, FMNH P 14238, FMNH P 14243, FMNH P 13733, MNPA-V n/n (ex MUT 166), MNPA-V n/n (ex MUT 299), NRM-M 4444]. In dorsal view (Figure $1 \mathrm{a}$ and $\mathrm{b}$ ), the skull shows a sub-rectangular contour, while the sagittal crest is much more developed in C. tarijensis [MNHN TAR 1260, FMNH P 13733, MNPA-V 005769, MNPA-V 005750 (ex MUT-V 32), MNPA-V n/n (ex MUT 166), MNPA-V n/n (ex MUT 299), NRM-M 4444, MACN 1138] than in C. chiliensis and Valgipes bucklandi (see Miño- 
Boilini 2016). In lateral view (Figure 1c and d), the pterygoid is like a plane leaf as observed in all scelidotheres, with this structure much more developed in C. tarijensis than in Scelidotherium spp. and Valgipes bucklandi (see Miño-Boilini 2016). In palatal view (Figure 1e), the palatal plane has a strong groove along the mid longitudinal ridge [FMNH P 14238, FMNH P 14243, MNPA-V 005750 (ex MUT-V 32), MNPA-V 005766 (ex MUT 298), MNPA-V n/n (ex MUT 299), NRM-M 4444]. In occlusal view (Figure 1e and f), the Mf1 of $C$. tarijensis is more mesiodistally extended than the rest of Quaternary scelidotheres, whereas the lingual lobe is well developed as in Quaternary scelidotheres (McDonald 1987, Miño-Boilini 2012, Plate 1, 2016); the Mf2, Mf3, and Mf4 are sub-triangular, with a lingual groove delimiting two defined lobes (see Miño-Boilini 2012, Plate, 1; Miño-Boilini 2016). As in other Quaternary scelidotheres, the Mf5 of $C$. tarijensis has a shallow lingual groove (Miño-Boilini 2016).

\section{Dentary}

In lateral view (Figure 1c and d), the horizontal ramus of $C$. tarijensis is higher than in Quaternary scelidotheres (e.g.: Scelidotherium spp., $V$. bucklandi), with the ventral margin markedly convex [MNHN TAR 1260, FMNH P 14238, MNPA-V 005769, MNPA-V 005750 (ex MUT-V 32), MNPA-V n/n (ex MUT 166), MNPA-V 005766 (ex MUT 298), among other specimens] (see McDonald 1987, Miño-Boilini 2012). In occlusal view, the mandibular symphysis is transversally wider than in the remaining Quaternary scelidotheres (e.g.: Scelidotherium spp., V. bucklandi, and $C$. chiliensis) (Miño-Boilini 2012, 2016) [FMNH P 14243, MNPA-V 005769, MNPA-V n/n (MUT 368)]. The $\mathrm{mfl}$ (Figure 1g, h and i) of C. tarijensis is much more extended mesiodistally than the homologous of the other Quaternary scelidotheres (e.g.: Scelidotherium spp., V. bucklandi, and $C$. chiliensis) (see McDonald 1987, Miño-Boilini 2012, Plate 2, 2016). This species has a lingual lobe with a slightly developed longitudinal groove; the $\mathrm{mf} 2$ and $\mathrm{mf} 3$ are sub-rectangular in cross section, with its maximum diameter oblique to the sagittal plane, as in all Scelidotheriinae, and that of $\mathrm{mf} 4$ is trilobated, as in the remaining scelidotheres (see McDonald 1987, Miño-Boilini 2012, Plate 2).

\section{Postcranial elements}

According to McDonald (1987) there are little anatomical differences among scapulae of Mylodontidae. The scapula of C. tarijensis (Figure 1j) has an isosceles triangle shape, as those of Quaternary scelidotheres (Scelidotherium spp., Catonyx spp., V. bucklandi) (see Miño-Boilini 2012 Plate 3, 2016). In lateral view, the scapula of $C$. tarijensis is antero-posteriorly wide and its lamina is thin. The supraspinous fossa is sub-triangular in shape, and the infraspinous fossa is slightly sub-rectangular, both characters as in the other Quaternary Scelidotheriinae species (see MiñoBoilini 2012, Plate 3). In C. tarijensis the spinal of the acromion is more massive than in C. cuvieri, C. chiliensis, Valgipes bucklandi, Scelidotherium leptocephalum, and S. bravardi.

The diaphysis of the humerus of $C$. tarijensis (Figure 1k) is more robust and massive with the deltoid tuberosity more developed than those of other Quaternary scelidotheres (e.g., Scelidotherium spp., V. bucklandi, and C. chiliensis) (see Miño-Boilini 2012, Plate. 4, 2016) [FMNH P 14238, MNPA-V 005752].

Catonyx tarijensis has entepicondylar foramen as in most of the Plio-Pleistocene scelidoterines (see Miño-Boilini 2012, Plate 4; Miño-Boilini 2016), except for $C$. cuvieri in which it is absent. In anterior view, it can be seen that the major tuberosity and the deltoid crest are well developed in C. tarijensis. As in all Scelidotheriinae the 
smaller tuberosity is slightly below the line of the humeral head (see Miño-Boilini 2012, Plate 4).

The ulna and radius (Figure 11) of $C$. tarijensis are clearly robust and massive (e.g.: Scelidotherium spp., V. bucklandi, and C. chiliensis) (see MiñoBoilini 2012, Plates 5 and 6, 2016) [FMNH P 14238, MNPA-V 005752]. The olecranon process of the ulna of $C$. tarijensis is more robust than that of Scelidotherium spp., Valgipes bucklandi, and Catonyx spp. (see Miño-Boilini 2016). The styloid process of the ulna is more robust in $C$. tarijensis than in Scelidotherium leptocephalum, S. bravardi, V. bucklandi, C. cuvieri, and C. chiliensis (see Miño-Boilini 2012, Plate 5). The inner border of the radius of $C$. tarijensis is more sinuous compared to Scelidotherium leptocephalum, S. bravardi, $V$. bucklandi, C. cuvieri, and C. chiliensis (see MiñoBoilini 2012, Plate 6).

The femur of $C$. tarijensis (Figure $1 \mathrm{~m}$ ) is rectangular, massive and transversely wide, with short femoral neck (see Miño-Boilini 2016). In anterior view, the patellar trochlea of $C$. tarijensis is more anteriorly positioned than in $C$. cuvieri, C. chiliensis, C. cuvieri, Scelidotherium leptocephalum, and $S$. bravardi. In proximal view, the femoral head is hemispherical, as observed in all Quaternary Scelidotheriinae. Its lateral epicondyle is more acute than in Scelidotherium spp. and Valgipes bucklandi (see Miño-Boilini 2012, Plate 8, 2016) [FMNH P 14238, MACN 1139].

In distal view, the patellar trochlea of $C$. tarijensis is continuous with the lateral and medial condyles, as in C. cuvieri, C. chiliensis, Scelidotherium leptocephalum and $S$. bravardi. However, in $V$. bucklandi they are separated by non-articular bone (Miño-Boilini 2012). In $C$. tarijensis, the medial condyle is more massive than in C. cuvieri, C. chiliensis, Scelidotherium leptocephalum and S. bravardi.

\section{DISCUSSION AND CONCLUSIONS}

\section{MORPHOLOGY AND TAXONOMY}

All the scelidothere remains of TarijaPadcaya basin are assigned to a single species, Catonyx tarijensis, on the basis of the following morphological characteristics: 1) skull with evident temporal ridges and sagittal crest, much better developed than in other Quaternary scelidotherines; 2) Mf1 mesiodistally extended with well-developed lingual lobe; 2) robust mandible, high horizontal ramus and ventral margin markedly convex; 3) mf1 with labial lobe having a slightly longitudinal groove; 4) robust and massive humerus with deltoid tuberosity more developed than in the remaining species; and 5) femur with short femoral neck.

In summary, Catonyx tarijensis is the only Scelidotheriinae recorded in the TarijaPadcaya basin. It is represented by several skulls, mandibles and postcranial elements. In turn, the hypothetical presence of the small Scelidotheriinae Scelidotherium patrium (see Boule and Thévenin 1920: 222) is rejected, according to the current evidence. Noteworthy, the materials assigned to this latter species (Scelidotherium patrium), currently housed in the MHNH TAR, were not figured (see Boule and Thévenin 1920). The preservation of these materials is bad, hindering a specific taxonomic assignation (C. Argot, pers. comm.), but very likely they belong to juveniles of $C$. tarijensis [MNPA-V s / n, ex MUT 452 (Figure 1f), MNPA-Vs / n, ex MUT 451 (Figure 1h and i), MNPA-V s / n, ex MUT 443 and 438]. On the other hand it is important to remark that Scelidotherium patrium (currently Proscelidodon patrius) is recorded in Pliocene sediments of Argentina and Bolivia (Anaya and MacFadden 1995, Miño-Boilini et al. 2011). In this scenario, the analyzed material (a left maxilla; MNPA-V s / n, ex MUT 452 (Figure 1f) shows evident sutures, which clearly indicate the early ontogenetic stage of the specimen. The taxonomic assignment to 
the species $C$. tarijensis is based on the particular morphology of the Mf1, which is mesiodistally extended, showing a very well developed lingual lobe. In turn, the hemimandibles (MNPA-V s / n, ex MUT 443 and 438) have a bulge in the body of the mandible; in addition, the lingual lobe of $\mathrm{mfl}$ has a slightly marked longitudinal sulcus. This particular morphology is only observed in juvenile specimens of C. tarijensis.

The other species mentioned for the Tarija Valley is Scelidotherium capellini (see Sefve 1915a and Takai et al. 1982), a taxon recognized by Gervais and Ameghino (1880) on the basis of a left dentary from the Pleistocene of the Buenos Aires province (Argentina) (see Miño-Boilini 2016, Figure 1g). In the type material of Scelidotherium capellini the ventral border of the mandible is convex, and the lingual lobe of mfl shows a slightly marked longitudinal sulcus, as observed in C. tarijensis. This taxonomic interpretation is in agreement with the proposal of Hoffstetter (1963) and McDonald and Perea (2002) according to which this species is a junior synonym of $C$. tarijensis (see also MiñoBoilini 2016). Moreover, this interpretation is also in agreement with McDonald (1987) who supports that the only recorded species in the Tarija Valley is C. tarijensis.

\section{BIOGEOGRAPHY AND CHRONOSTRATIGRAPHY}

According to Miño-Boilini (2012) the biogeographic history of the Scelidotheriinae was restricted with certainty to South America, so far this clade has not been found in Central or North America. Scelidotherines are recorded from the middle Miocene to the early Holocene in Argentina, Bolivia, Brazil, Chile, Colombia, Ecuador, Peru, Paraguay, and Uruguay (Miño-Boilini and Carlini 2009).

More precisely, C. tarijensis has a wide paleontological record in South America (MiñoBoilini 2016). In Argentina, it is recorded in Buenos
Aires, Córdoba, Corrientes, and Salta provinces, from the Ensenadan to Lujanian ages (early-middle Pleistocene to late Pleistocene) (see McDonald 1987, Miño-Boilini 2012, 2016). The first records of $C$. tarijensis come from early-middle Pleistocene sediments of several localities (e.g. "Toscas" del Río de La Plata, Olivos, Florida; see MiñoBoilini 2016). In Uruguay, C. tarijensis is recorded from the early-middle Pleistocene (Ensenadan Stage) to the late Pleistocene (Lujanian Stage) of the departments of San José and Canelones, respectively (McDonald and Perea 2002, Corona et al. 2013).

Taking into account that the age of the TarijaPadcaya basin is controversial (see Tonni et al. 2009, MacFadden et al. 2013), with ages that range between the Ensenadan and Lujanian (MacFadden et al. 2013, Coltorti et al. 2007, 2010, Zurita et al. 2009, Tonni et al. 2009), the presence of $C$. tarijensis supplies no information to support any of the chronological hypotheses mentioned above.

\section{ACKNOWLEDGMENTS}

We are indebted to Dr. A. Kramarz (MACN), Ing. F. Paredes Ríos (MNPA), Dr. L. Werdelin (NRM) and Dr. W.F. Simpson (FMNH) for the access to collections under their care. To Dr. C. Argot (MHNH) for supplying photographs of the holotype of Scelidotherium tarijensis. Four anonymous reviewers made helpful comments that improved the manuscript. This paper was partially financed by PI Q003/2014 (SGCyT-UNNE).

\section{REFERENCES}

AMEGHINO F. 1888. Rápidas diagnosis de algunos mamíferos fósiles nuevos de la República Argentina. P E Coni, p. 1-17.

AMEGHINO F. 1891. Mamíferos y aves fósiles argentinas. Especies nuevas, adiciones y correcciones. Rev Arg de Cienc Nat 1: 240-259.

AMEGHINO F. 1902. Notas sobre algunos mamíferos fósiles nuevos o poco conocidos del valle de Tarija. An del Mus Nac de Buenos Aires 8: 225-261. 
AMEGHINO F. 1904. Nuevas especies de mamíferos cretáceos y terciarios de la República Argentina. An de la Soc Cien Arg 56-71: 225-291.

ANAYA F AND MACFADDEN B. 1995. Pliocene mammals from Inchasi, Bolivia: the endemic fauna just before the Great American Interchange. Bull of the Florida Mus of Nat Hist 39: 87-140.

BOULE M AND THÉVENIN A. 1920. Mammifères fossiles de Tarija, vol. 4. Imprimerie Nacional, Paris, $256 \mathrm{p}$.

CIONE AL, GASPARINI GM, SOIBELZON E, SOIBELZON LH AND TONNI EP. 2015. The Great American Biotic Interchange in Southern South America: land mammal biostratigraphy, climatic evolution and faunal integration. Springer Briefs in Earth System Sciences. New YorkLondon, 96 p.

COLTORTI M, ABBAZZI L, FERRETI M, LACUMIN P, PAREDES RÍOS F, PELLEGRINI M, PIERUCCINI P, RUSTIONI M, TITO G AND ROOK L. 2007. Last Glacial mammals in South America: a new scenario from the Tarija Basin (Bolivia). Naturwissenschaften 94: 288-299.

COLTORTI M, PIERUCCINI P AND PAREDES RÍOS F. 2010. Late Pleistocene stratigraphy, sedimentology and paleoenvironmental evolution of the Tarija-Padcaya basin (Bolivian Andes). Proc Geol Assoc 121(2): 162-179.

COPE ED. 1889. The edentata of North America. Amer Midl Natur 23: 657-664.

CORONA A, PEREA D AND MCDONALD HG. 2013. Catonyx cuvieri (Xenarthra, Mylodontidae, Scelidotheriinae) from the late Pleistocene of Uruguay, with comments regarding the systematics of the subfamily. J Vert Paleontol 33(5): 1214-1225.

DE IULIIS G, PUJOS F AND TITO G. 2009. Systematic and taxonomic revision of the Pleistocene ground sloth Megatherium (Pseudomegatherium) tarijense (Xenarthra: Megatheriidae). J Vert Paleontol 29: 1244-1251.

GERVAIS H AND AMEGHINO F. 1880. Los Mamíferos de la América Meridional. Sabih e Igon. Paris-Buenos Aires, $225 \mathrm{p}$.

GERVAIS P. 1855. Recherches sur les mammifères fossiles de l'Amérique méridionale. In: Francis L. de Laporte de Castelnau, Animaux nouveaux ou rares recueillis pendant l'expédition dans les parties centrales de l'Amérique du Sud, de Rio de Janeiro à Lima, et de Lima au Para: exécuté par ordre du gouvernement français pendant les années 1843 à 1847. Paris I(Pt 1): 1-63.

GERVAIS P. 1874. Lestodon trigonidens et Valgipes deformis. J de Zoolog 3: 162-164.

HOFFSTETTER R. 1963. La faune pléistocéne de Tarija (Bolivie). Bull Mus Nat Hist Natur 35: 194-203.

LATHAN J AND DAVIES H. 1795. Faunula indica. Appendix to Forster, J. R. Zoologia indica, Ed. Secunda. Gebauer, Halle, 38 p.
LUND PW. 1839. Extrait d'une letter de M. Lund, écrite de Lagoa Santa (brésil), le 5 novembre 1838, et donnant un aperçu des espèces de mammifères fossiles qu'il a découvertes au Brésil. Comp Rend de l'Académie des Sci 8: 570-577.

LYDEKKER R. 1886. Description of three species of Scelidotherium. Proc of the Zool Soc of London 32: 491498.

MACFADDEN BJ, ZEITLER PK, ANAYA F AND COTTLE JM. 2013. Middle Pleistocene age of the fossiliferous sedimentary sequence from Tarija, Bolivia. Quat Resear 79: 268-273.

MARSHALL LG. 1978. Bolivian adventure: In search of the bones of giants. Bull Field Mus of Nat Hist 49: 16-23.

MCDONALD HG. 1987. A Systematic review of the PlioPleistocene Scelidotherinae group sloth (Mammalia: Xenarthra: Mylodontidae). (Ph.D. thesis). Toronto, Canada: University of Toronto, Canada, $478 \mathrm{p}$.

MCDONALD HG AND PEREA D. 2002. The large Scelidothere Catonyx tarijensis (Xenarthra, Mylodontidae) from the Pleistocene of Uruguay. J Vert Paleontol 22(3): 677-683.

MIÑO-BOILINI AR. 2012. Sistemática y evolución de los Scelidotheriinae (Xenarthra, Mylodontidae) cuaternarios de la Argentina. Importancia bioestratigráfica, paleobiogeográfica y paleoambiental. (Ph.D. thesis). La Plata, Argentina: Facultad de Ciencias Naturales y Museo, Universidad Nacional de La Plata, 317 p.

MIÑO-BOILINI AR. 2016. Additions to the knowledge of the ground sloth Catonyx tarijensis (Xenarthra, Pilosa) in the Pleistocene of Argentina. PalZ 90: 173-183.

MIÑO-BOILINI AR AND CARLINI AA. 2009. The Scelidotheriinae Ameghino, 1904 (Phyllophaga, Xenarthra) from the Ensenadan-Lujanian Stage/Ages (Early Pleistocene to Early-Middle Pleistocene-Early Holocene) of Argentina. Q Internat 210: 93-100.

MIÑO-BOILINI AR, TOMASSINI RL, OLIVA C AND MANERA DE BIANCO T. 2011. Adiciones al conocimiento de Proscelidodon Bordas (Mammalia, Xenarthra, Scelidotheriinae). Rev Bras de Pal 14: 269-278.

NORDENSKIÖLD E. 1902. Über die Saügetierfossilien in Tarijathal. Bull Geol Inst Univ of Uppsala 5: 261-266.

OPPENHEIM V. 1943. The fossiliferous basin of Tarija, Bolivia. J Geol 51(8): 548-555.

OWEN R. 1839. Fossil Mammalia (3). In: The Zoology of the Voyage of H.M.S. Beagle (C. Darwin., editor). Simth. Elder and Co., p. 65-80.

PASCUAL R, ORTEGA EJ, GONDAR DG AND TONNI EP. 1966. Vertebrata I. In: Borello AV (Ed), Paleontografía Bonaerense. Comisión de Investigaciones Científicas de la provincia de Buenos Aires, 202 p.

PHILIPPI RA. 1893. Noticias preliminares sobre los huesos fósiles de Ulloma. Anal Univer Chile 82: 499-506. 
RODRÍGUEZ-BUALÓ SM, SOIBELZON E, SCARANO AC AND ZURITA AE. 2014b. Chaetophractus tarijensis (Xenarthra, Dasypodidae) ¿Un endemismo del valle de Tarija (Bolivia)? Implicancias paleobiogeográficas. Rev Bras Paleontol 17(1): 59-68.

RODRÍGUEZ-BUALÓ SM, ZURITA AE, GOIS F, MIÑOBOILINI AR, SOIBELZON E AND PAREDES RÍOS F. 2014a. Pampatheriidae (Xenarthra, Cingulata) from Tarija Valley, Bolivia: A taxonomic update. Riv Ital Paleontol e Stratigraf 120(2): 253-259.

RODRÍGUEZ-BUALÓ SM, ZURITA AE, SOIBELZON E, GONZÁLEZ-RUIZ L AND PAREDES-RÍOS F. 2017. The Cingulata Dasypodidae (Mammalia, Xenarthra) in the Tarija Valley (Bolivia): a particular assemblage in South America. Boll della Soc Paleo Italiana 56(1): 35-43.

SEFVE I. 1915a. Ueber einen Scelidotherium-Schädelaus Tarija, Bolivia. Kung Sven Vetenskaps-akadmiens Handlingar Stockholm Bd 53: 1-12.

SEFVE I. 1915b. Scelidotherium-reste aus Ulloma, Bolivia. Bull Geol Inst Uppsala 13: 61-92.

SUÁREZ-MONTERO M. 1996. Geología del Cuaternario de la cuenca pleistocena de Tarija. XII Congreso Geológico de Bolivia, Memorias, p. 455-463.

TAKAI F, AROZQUETA B, MIZUNO T, YOSHIDA A AND KONDO H. 1984. On fossil mammals from the Tarija department, Southern Bolivia. The Res Inst of Evol Biol 4: 1-63.

TAKAI F, MIZUNO T, IWASAKI Y, TANAKA K AND YOSHIDA A. 1982. Tarija mammal-bearing formation in Bolivia. The Res Inst of Evol Biol 3: 1-72.

TONNI EP, SOIBELZON E, CIONE AL, CARLINI AA, SCILLATO YANÉ GJ, ZURITA AE AND PAREDES RÍOS F. 2009. Preliminar correlation of the Pleistocene sequences of the Tarija valley (Bolivia) with the Pampean chronological standard. Q Inter 210: 57-65.

WEDDELL HA. 1851. Voyage dans le sud de la Bolivie. In: F. de Castelnau (Ed), Expedition dans les parties centrales de 1'Amérique du sud, de Rio de Janeiro à Lima au Para; exécute par ordre du gourverment français pendant les années 1843 á 1847 sous la direction de F. de Castelnau. Historie du Voyage, $432 \mathrm{p}$.

WERDELIN L. 1991. Pleistocene vertebrates from Tarija, Bolivia in the collection of the Swedish Museum of Natural History. Rev Téc Yac Petrol Fisc Bol 12: 673684.

ZURITA AE, MIÑO-BOILINI AR, SOIBELZON E, CARLINI AA AND PAREDES RÍOS F. 2009. The diversity of Glyptodontidae (Xenarthra, Cingulata) in the Tarija Valley (Bolivia): systematic, biostratigraphic and paleobiogeographic aspects of a particular assemblage. $\mathrm{N}$ Jahr Geol P-A 251(2): 225-237. 